\title{
Nutritional composition and evaluation of different methodologies for fat determination in wet feed for dogs and cats
}

\section{Composição nutricional e avaliação de diferentes métodos de determinação de gordura em alimentos úmidos para cães e gatos}

\author{
Maria Isabel Gonzalez URREGO'ㄹ ${ }^{1}$ Mariane Ceschin ERNANDES²; Laura Fantucci de Oliveira MATHEUS²; \\ Karine de Melo SANTOS²; Patrícia Massae OBA²; Cláudio Galeno Piantino SILVA²; Thiago Henrique Annibale \\ VENDRAMINI ${ }^{2}$; Vivian PEDRINELLI ${ }^{3}$; Márcio Antonio BRUNETTO² \\ ${ }^{1}$ Universidade de São Paulo, Faculdade de Medicina Veterinária e Zootecnia, Departamento de Nutrição e Produção Animal, Pirassununga - SP, Brazil \\ ${ }^{2}$ Universidade de São Paulo, Faculdade de Zootecnia e Engenharia de Alimentos, Departamento de Zootecnia, Pirassununga - SP, Brazil \\ ${ }^{3}$ Universidade de São Paulo, Faculdade de Medicina Veterinária e Zootecnia, Departamento de Clínica Veterinária, São Paulo - SP, Brazil
}

\begin{abstract}
As a consequence of the increasing number of dog and cat owners, the pet food industry is expanding the range of pet food products in the market. In order to obtain more necessary information about the wet food segment for dogs and cats, the aim of this study was to determine the nutritional composition, to evaluate the information declared on the labels, and to compare the composition with the FEDIAF recommendations for protein and fat. Furthermore, three different methodologies of fat analysis were compared: crude fat (CFa), crude fat after acid hydrolysis (CFAH), and fat content obtained with Ankom XT15 (ANKOM) to determine the most adequate method for fat determination in wet foods. Twenty-five wet food products were evaluated, 13 wet foods for dogs and 12 for cats. Centesimal composition analyses obtained in this study were compared with guaranteed analysis declared on the label and with FEDIAF minimum recommended requirements for each species. The results of the nutritional composition and the values described on the label and the evaluation of the three fat determination methods were compared using the mixed model test with repeated measurements in the same samples, respectively $(\mathrm{p}<0.05)$ in the SAS program, evaluation of protein adequacy and fat content were analyzed by mathematical calculations of difference and proportion. No difference was observed between nutritional composition of wet foods and the values declared on the labels for the majority of the diets analyzed, and there was a predominance of products that exceeded FEDIAF minimum recommendations of protein and fat for both species. No difference was observed between the three methods of fat content evaluation $(\mathrm{p}=0.68)$. It was concluded that wet foods evaluated in this study match the label information and FEDIAF nutrient requirement recommendations, considering recommended calorie intake. All three fat determination methodologies evaluated were similar, justifying the choice of the easiest or cheapest method.
\end{abstract}

Keywords: Canned food. Pouched food. Canine. Feline. Acid hydrolysis.

\section{Resumo}

Devido ao aumento do número de cães e gatos domiciliados, a indústria de alimentos para animais de estimação tem expandido a gama de produtos existentes no mercado de pet food. Para obter informações mais relevantes sobre o segmento de alimentos úmidos para cães e gatos, este trabalho determinou a composição nutricional, avaliou as informações declaradas nos rótulos e comparou a composição com as recomendações da Fediaf de proteína e gordura. Também foram comparadas três metodologias diferentes de análise de gordura: extrato etéreo $(\mathrm{CFa})$, extrato etéreo após hidrólise ácida $(\mathrm{CFAH})$ e teor de gordura obtido no analisador Ankom XT15 (ANKOM) para determinar o método mais adequado de avaliação de gordura em alimentos úmidos. Foram avaliadas 25 marcas de alimentos úmidos, 13 para cães e 12 para gatos. As análises de composição centesimal obtidas neste estudo foram comparadas com a informação nutricional declarada nos rótulos e com as necessidades mínimas recomendadas pela Fediaf para cada espécie. Os resultados da composição nutricional, os valores descritos no rótulo e a avaliação dos três métodos para determinação da gordura foram comparados com o emprego do teste t e modelo misto com medidas repetidas nas mesmas amostras, respectivamente $(\mathrm{p}<0,05)$ no programa SAS. Já a avaliação da adequação nutricional de proteína e do teor de gordura foram analisados por cálculos matemáticos de diferença e proporção. Para a maioria dos alimentos avaliados não foi observada diferença entre a composição nutricional dos alimentos úmidos e os valores declarados em rótulo, e houve predominância de produtos que excederam as recomendações mínimas de proteína e gordura da Fediaf para ambas as espécies. Quanto às metodologias de extração de gordura, não foi observada diferença entre os três métodos avaliados $(\mathrm{p}=0,68)$. Concluiu-se que os alimentos úmidos avaliados atendem às informações declaradas pelos fabricantes e também às recomendações nutricionais da Fediaf com base na ingestão energética recomendada. Em relação às metodologias avaliadas para determinação de gordura nestes alimentos, a similaridade entre tais resultados justifica o uso da técnica de maior facilidade ou de menor custo.

Palavras-chave: Alimentos enlatados. Alimentos em sachê. Canino. Felino. Hidrólise ácida. 
Correspondence to:

Márcio Antonio Brunetto

Universidade de São Paulo, Faculdade de Medicina Veterinária

e Zootecnia, Departamento de Nutrição e Produção Animal

Av. Duque de Caxias Norte, 225

CEP 13635-900, Pirassununga, SP, Brazil

e-mail: mabrunetto@usp.br

Received: 31/05/2017

Approved: 13/12/2017

\section{Introduction}

Commercial pet food products for dogs and cats in Brazil may be classified based on different parameters, one of them being moisture. Pet foods can be ranked as dry food (maximum moisture of 12\%), semi-moist food (moisture between 12 and 30\%), and wet food (moisture between 30 and 84\%) (BRASIL, 2009a).

Wet foods usually present moisture content between $74 \%$ and $84 \%$, which makes this type of food an important source of water intake, especially for cats (NATIONAL RESEARCH COUNCIL, 2006; WEI et al., 2011). Pet foods with high moisture content also have more fresh or frozen meat and its coproducts, which contain high levels of protein, phosphorus, sodium, and fat (HAND et al., 2010). Studies on nutritional composition evaluation of dry foods for dogs and cats are common, but there are few studies on the composition of wet foods and comparison of the nutritional composition analysis and the label information.

The crude fat content of pet foods can be determined with different chemical and physical analysis methods. Soxhlet is the most commonly used methodology for determination of lipid content of a sample, but it depends on the substance that is analyzed, as described by Silva and Queiroz (2002). This method consists in the estimation of fat in a sample using the Soxhlet extractor and non-polar solvents like petroleum ether. An alternative for Soxhlet method is based on filtering bags technology, developed by Ankom Technology Inc. (Macedon, NY) (LIU, 2011). This alternative methodology was approved by AOAC in 2005 (ASSOCIATION OF THE OFFICIAL ANALYTICAL CHEMISTS, 2005) and also uses ether, but in a closed system which decreases time for extraction.

The cooking procedure of dry pet food may denature proteins and cause starch gelatinization, which results in the formation of amylose-lipid complex and makes it more difficult to extract lipids with ether (LUMLEY; COLWELL, 1991; NRC, 2006). Therefore, the determination of crude

fat with acid hydrolysis (CFAH) is recommended for dry foods (NRC, 2006). The acid hydrolysis method breaks the amylose-lipid complex and makes fat quantification possible.

There is no information on the most effective method for fat extraction of wet pet food. Most wet products contain a relatively small portion of carbohydrates when compared to dry pet food, ranging from $4 \%$ to $13 \%$. This may be because of the different process, as extrusion demands higher starch content (NRC, 2006).

Thermal processes are frequently used in pet food to reach the physical format intended, and can be achieved with extrusion, cooking, and/or pasteurization, all of them increasing the nutrient digestibility (MURRAY et al., 2001; GRIFFIN, 2003; TRAN et al., 2008) and product shelf-life (LANKHORST et al., 2007). Wet foods undergo pasteurization after packaging to ensure nutrient stability and pathogen control (HAND et al., 2010). Furthermore, pasteurization does not create amylose-lipid complexes (ELIASSON, 2004; TESTER et al., 2004; VANDEPUTTE; DELCOUR, 2004), allowing perhaps the employment of simpler and cheaper methods of fat content assessment.

Considering the scarce literature regarding wet foods for dogs and cats, the aim of this study was to evaluate nutritional composition, evaluate nutritional adequacy within FEDIAF recommendations for each species, and compare results of nutritional analysis with label information, as well as to compare different methodologies for determination of fat content in this type of food intended for dogs and cats.

\section{Material and Methods}

Twenty-five wet food products complete and balanced, thirteen for dogs and twelve for cats, were acquired during the second semester of 2016 in the cities of Campinas and Pirassununga (São Paulo - Brazil), all intended for healthy adult dogs or cats, canned or in pouches, from 13 different manufacturers. The products were renamed for this study in order to preserve the manufacturers' privacy, and afterwards a sampling was performed with retrieval of significant and homogenous amount of each product.

\section{Nutritional composition analysis}

Centesimal composition analyses were performed at the Multiuser Laboratory of Animal Nutrition and Bromatology of the Department of Nutrition and Animal 
Production of the School of Veterinary Medicine and Animal Science of the University of São Paulo.

Product samples were dehydrated in forced ventilation chamber at $55^{\circ} \mathrm{C}$ for 72 hours, according to method proposed by AOAC (2006) (method 930.15). The diets were grounded in a grain mill with a $1 \mathrm{~mm}$ sieve, and dry matter (DM) was determined by oven drying at $105^{\circ} \mathrm{C}$. Nitrogen content was determined by Kjedhal method, crude fiber (CFi) content was determined by Weende method, crude fat $(\mathrm{CFa})$ was determined by traditional method using a Soxhlet system with no previous hydrolisis AOAC (2006) (method 920.39), and ash (A) content was determined by AOAC (2006) (method 942.05). All analyses were performed in duplicate and were repeated when difference between samples was more than 5\%. Results were compared with label information on guaranteed analysis using $\mathrm{t}$ test $(\mathrm{p}<0.05)$ with Statistical Analysis System (SAS, version 9.4).

\section{Evaluation of nutritional adequacy of protein and fat content}

The results of the laboratorial analyses of crude protein and crude fat were compared with the recommendations of daily protein and fat intake according to FEDIAF (2016). The minimum recommendations of protein and fat in $\mathrm{g} / 100 \mathrm{~g}$ of dry matter was estimated considering energy intake of $95 \mathrm{kcal} / \mathrm{kg}^{0,75}$ for dogs and $100 \mathrm{kcal} / \mathrm{kg}^{0,67}$ for cats (FEDIAF, 2016).

Minimum requirement allowance of fat and protein contents of each product tested was verified with Microsoft Excel (2010).

\section{Evaluation of three methods for determination of crude fat}

In evaluation of different methodologies for determination of fat content of wet foods, this study used 14 products for healthy adult dogs and cats, canned or in pouches. Seven of these products were intended for dogs and seven were intended for cats, from five different manufacturers, acquired in pet stores located in the cities of Pirassununga and Campinas (São Paulo - Brazil).

All samples were analyzed using three methodologies tested in this study: crude fat ( $\mathrm{CFa}$ ), crude fat after acid hydrolysis (CFAH), and fat content obtained with Ankom XT15 (ANKOM). The method of CFa was performed according to AOAC (2006) (method 920.39), using a
Soxhlet system. Two grams of each product were kept for 7 hours in the Soxhlet extractor, with qualitative filtering paper of $80 \mathrm{~g} / \mathrm{m}^{2}$ grammage using petroleum ether as the solvent. After recovering the ether, containers were kept in an oven at $105^{\circ} \mathrm{C}$ for 12 hours, removed from the oven, and put in a room-temperature desiccator for cooling down. After cooling down the fat content was determined by gravimetric analysis.

For CFAH the method described by AOAC (2006) (method 954.02) was used. Samples were predigested with hydrochloric acid at $40 \%(\mathrm{HCl} 40 \%)$ for 45 minutes after boiling, in constant temperature of $250^{\circ} \mathrm{C}$ - fifty milliliters of $\mathrm{HCl} 40 \%$ and $3 \mathrm{~g}$ of sample in beckers. After digestion, the becker content was filtered with qualitative filtering paper of $80 \mathrm{~g} / \mathrm{m}^{2}$ and funnel. Filtering paper was then taken to the Soxhlet equipment and kept in it for 7 hours. Afterwards, the glass balloon was put in a laboratory stove at $105^{\circ} \mathrm{C}$ for 12 hours, and then put in the desiccator in room temperature to cool down and to be weighted. Fat content was determined by gravimetric analysis and was expressed in percentage.

The ANKOM method is an automated methodology in which the extraction process is performed using bags from Ankom Technology (XT4 filter bag) and petroleum ether extraction, without previous ether hydrolysis, conducted at $90^{\circ} \mathrm{C}$ in a closed system, which increases velocity of extraction to 60 minutes at most. One gram of sample material was placed in a filter bag, weighed, and then sealed to reduce risk of contamination. Sealed bags were then put in an oven for 30 minutes, and then placed in a room-temperature desiccator to cool down. After reaching room temperature the bags were placed in Ankom XT15 fat analyzer. Following extraction, samples were dried in an oven, cooled in the desiccator, and then weighed.

A 5\% significance was considered for comparison of the three techniques used to estimate crude fat, using mixed-model with repeated analysis of same samples and considering samples as a random effect and fixed effect as a methods of analysis in the Statistical Analysis System (SAS, version 9.4).

\section{Results and Discussion}

The nutritional composition and nutritional analyses are described on a dry matter basis in Tables 1 and 2, comparing between the laboratory analysis and label information. 
Table 1 - Nutritional composition analyses values and guaranteed analysis on label, in percentage of dry matter, in wet foods for healthy adult dogs - FMVZ/USP, Pirassununga (SP) - 2017

\begin{tabular}{|c|c|c|c|c|c|c|c|c|c|c|}
\hline Items & $\begin{array}{c}\text { Moisture } \\
\text { analysis }\end{array}$ & $\begin{array}{l}\text { Moisture } \\
\text { label }\end{array}$ & $\begin{array}{c}\text { Ash } \\
\text { analysis }\end{array}$ & Ash label & $\begin{array}{l}\text { Crude fat } \\
\text { analysis }\end{array}$ & $\begin{array}{c}\text { Crude fat } \\
\text { label }\end{array}$ & $\begin{array}{c}\text { Crude } \\
\text { fiber } \\
\text { analysis }\end{array}$ & $\begin{array}{l}\text { Crude } \\
\text { fiber } \\
\text { label }\end{array}$ & $\begin{array}{l}\text { Crude } \\
\text { protein } \\
\text { analysis }\end{array}$ & $\begin{array}{c}\text { Crude } \\
\text { protein } \\
\text { label }\end{array}$ \\
\hline \multicolumn{11}{|c|}{ Dogs } \\
\hline Food A & 77.57 & 78.73 & 12.93 & 16.66 & 30.80 & 27.77 & 10.50 & 11.11 & 46.77 & 44.44 \\
\hline Food B & 79.23 & 78.89 & 6.34 & 11.84 & 10.72 & 13.16 & 2.73 & 3.94 & 20.68 & 31.58 \\
\hline Food C & 77.08 & 77.18 & 10.48 & 13.16 & 25.84 & 26.32 & 4.00 & 7.89 & 40.70 & 47.37 \\
\hline Food D & 80.46 & 82.05 & 9.11 & 13.15 & 22.05 & 31.57 & 3.21 & 10.52 & 38.07 & 42.10 \\
\hline Food E & 70.84 & 72.85 & 12.33 & 28.00 & 23.09 & 28.00 & 11.12 & 20.00 & 56.09 & 60.00 \\
\hline Food F & 80.02 & 79.69 & 9.21 & 16.66 & 18.98 & 16.66 & 5.32 & 11.11 & 46.72 & 44.44 \\
\hline Food G & 77.42 & 78.57 & 10.19 & 13.15 & 22.28 & 26.31 & 4.70 & 7.89 & 41.65 & 47.36 \\
\hline Food $\mathrm{H}$ & 79.07 & 78.73 & 11.25 & 13.15 & 24.65 & 26.31 & 5.55 & 7.89 & 44.54 & 42.10 \\
\hline Food I & 76.93 & 77.03 & 4.90 & 13.15 & 12.87 & 26.31 & 2.29 & 7.89 & 36.62 & 42.10 \\
\hline Food J & 78.12 & 79.66 & 10.36 & 16.66 & 36.33 & 27.77 & 11.07 & 11.11 & 39.28 & 44.44 \\
\hline Food K & 70.70 & 72.70 & 9.95 & 18.00 & 30.58 & 20.00 & 4.66 & 6.00 & 38.97 & 36.00 \\
\hline Food L & 79.86 & 79.53 & 6.97 & 16.66 & 19.40 & 22.22 & 4.91 & 11.11 & 42.17 & 44.44 \\
\hline Food M & 80.46 & 79.51 & 7.08 & 13.88 & 15.76 & 16.66 & 3.83 & 5.55 & 47.81 & 47.22 \\
\hline Mean & 77.52 & 78.09 & 9.32 & 15.70 & 22.57 & 23.77 & 5.68 & 9.39 & 41.54 & 44.12 \\
\hline MSE $^{1}$ & 0.900 & 0.737 & 0.662 & 1.163 & 2.027 & 1.534 & 0.867 & 1.105 & 2.262 & 1.823 \\
\hline$p$ & \multicolumn{2}{|c|}{0.072} & \multicolumn{2}{|c|}{$<0.0001$} & \multicolumn{2}{|c|}{0.517} & \multicolumn{2}{|c|}{0.001} & \multicolumn{2}{|c|}{0.055} \\
\hline
\end{tabular}

${ }^{1}$ MSE, mean standard error

Table 2 - Nutritional composition analyses values and guaranteed analysis on label, in percentage of dry matter, in wet foods for healthy adult cats - FMVZ/USP, Pirassununga (SP) - 2017

\begin{tabular}{|c|c|c|c|c|c|c|c|c|c|c|}
\hline Items & $\begin{array}{l}\text { Moisture } \\
\text { analysis }\end{array}$ & $\begin{array}{l}\text { Moisture } \\
\text { label }\end{array}$ & $\begin{array}{c}\text { Ash } \\
\text { analysis }\end{array}$ & Ash label & $\begin{array}{l}\text { Crude fat } \\
\text { analysis }\end{array}$ & $\begin{array}{c}\text { Crude fat } \\
\text { label }\end{array}$ & $\begin{array}{c}\text { Crude } \\
\text { fiber } \\
\text { analysis }\end{array}$ & $\begin{array}{c}\text { Crude } \\
\text { fiber label }\end{array}$ & $\begin{array}{c}\text { Crude } \\
\text { protein } \\
\text { analysis }\end{array}$ & $\begin{array}{c}\text { Crude } \\
\text { protein } \\
\text { label }\end{array}$ \\
\hline \multicolumn{11}{|c|}{ Cats } \\
\hline Food N & 78.98 & 79.65 & 5.91 & 15.63 & 21.25 & 37.50 & 2.77 & 9.37 & 38.11 & 38.11 \\
\hline Food O & 81.01 & 79.13 & 10.83 & 28.00 & 23.23 & 24.00 & 6.35 & 20.00 & 57.67 & 64.00 \\
\hline Food P & 74.74 & 76.88 & 11.78 & 20.00 & 29.85 & 17.50 & 6.09 & 10.00 & 48.52 & 50.00 \\
\hline Food Q & 80.94 & 81.33 & 6.29 & 10.85 & 14.46 & 11.42 & 2.62 & 9.14 & 57.08 & 57.14 \\
\hline Food R & 75.68 & 76.80 & 9.24 & 13.88 & 22.00 & 22.22 & 5.69 & 8.33 & 47.61 & 50.00 \\
\hline Food S & 78.82 & 79.49 & 6.50 & 13.88 & 32.92 & 16.66 & 4.35 & 5.55 & 44.54 & 47.22 \\
\hline Food T & 78.50 & 76.68 & 8.75 & 16.66 & 25.63 & 27.77 & 10.39 & 11.11 & 42.69 & 44.44 \\
\hline Food U & 74.59 & 76.73 & 5.64 & 12.50 & 14.90 & 12.50 & 3.86 & 7.50 & 59.22 & 55.00 \\
\hline Food V & 80.78 & 81.17 & 14.22 & 18.75 & 30.64 & 18.75 & 14.67 & 12.50 & 46.81 & 50.00 \\
\hline Food W & 75.53 & 76.65 & 6.24 & 13.50 & 14.15 & 10.00 & 2.29 & 7.50 & 58.55 & 55.00 \\
\hline Food X & 79.50 & 78.51 & 11.37 & 13.15 & 24.87 & 15.78 & 6.12 & 7.89 & 39.66 & 42.10 \\
\hline Food Y & 80.31 & 81.40 & 11.90 & 2.00 & 20.78 & 16.66 & 3.53 & 6.66 & 38.57 & 36.66 \\
\hline Mean & 78.28 & 78.70 & 9.06 & 14.90 & 22.89 & 19.23 & 5.73 & 9.63 & 48.25 & 49.14 \\
\hline $\mathrm{MSE}^{1}$ & 0.716 & 0.558 & 0.846 & 1.766 & 1.826 & 2.233 & 1.040 & 1.093 & 2.320 & 2.317 \\
\hline
\end{tabular}

${ }^{1}$ MSE, mean standard error 
A total of $38.5 \%$ of wet foods for dogs and $25 \%$ of wet foods for cats presented moisture values higher than declared on label. However, this variation of moisture analyzed with the moisture declared on the label of these foods was small and no differences were observed when comparing wet food for dogs $(\mathrm{p}<0.072)$ and wet food for cats $(\mathrm{p}<0.301)$. All wet foods for both species had moisture content analyzed from $70 \%$ to $82 \%$, proving to be a good source of water intake, especially for cats (NRC, 2006), and they could be considered the main involuntary source of ingestion of water for cats (CARCIOFI et al., 2006)

Difference between label information and nutritional analyses was observed for ash $(\mathrm{p}<0.01)$ and CFi $(\mathrm{p}<0.01)$ of wet foods for both dogs and cats, whose analysis values were lower than declared on label. In wet diets for cats, $91.7 \%$ of the diets analyzed also had higher ash and crude fiber values on the label information than the analyzed levels.

According to Brazilian legislation the guaranteed analysis levels for components that tend to compromise food quality when excessive, such as moisture, crude fiber, and ash, have maximum limits. These limits were determined because high levels of ash or crude fiber can decrease food digestibility (HUBER et al., 1986; EARLE et al., 1998; CARCIOFI et al., 2006). However, when the values obtained from the product are lower than label information, the product is still considered in accordance with the legislation (BRASIL, 2003). This lower content of ash, though still in accordance with the legislation, is expected when a source of protein that usually presents lower levels of ash than meat meals is used, considering that most wet food diets contain a higher inclusion of fresh meats. Excess mineral control is easier in wet foods for its higher content in fresh meat, avoiding excess of minerals, like calcium, magnesium, and phosphorus, which are more commonly present in meat meals used in dry foods (HAND et al., 2010). This protein-ash content ratio in ingredients is very important, especially when cats are concerned, as higher ash content in foods can predispose cats to uroliths (BARTGES, 2016; LULICH et al., 2016). The lower ash content allied with higher moisture justifies the use of wet foods to help treat, control, and prevent low urinary tract diseases in cats (HAND et al., 2010).

Similar to ash content, crude fiber content obtained through laboratorial nutritional analysis was also lower than label information in the vast majority of diets for dogs $(p<0.001)$ and for cats $(p=0.006)$. Some diets presented crude fiber content as low as one third of the expected value when compared to the information on the label. This difference between label information and laboratorial analysis can be explained by the limitation of crude fiber analysis, since this specific analysis estimates the whole content of fibrous material by obtaining part of the hemicellulose, cellulose, and lignin present in the food, underestimating its real content (NRC, 2006; DE-OLIVEIRA et al., 2012; FARCAS et al., 2013)

Dietary fiber is composed by a heterogenic group of compounds of vegetable source, which are resistant to digestion and absorption in the small intestine, but are partially or totally fermented by microorganisms in the large bowel, generating short-chain fatty acids that are a substrate for large intestine epithelial cells. Determination of total dietary fiber, as described by AOAC (2006), is performed by quantification of fiber substances using enzymes such as $a$-amylase, protease, and amyl glucosidase, which is a more precise method of determining the important fractions of fiber for intestinal fermentation (DE-OLIVEIRA et al., 2012; FARCAS et al., 2013).

Protein and fat are two macrocomponents that are sources of essential nutrients for dogs and cats, such as amino acids and fatty acids, and are fundamental for diet formulation for dogs and cats (NRC, 2006). Therefore, minimum inclusion limits are stated, and negative variations are not tolerated according to current legislation. However, levels above the label information are considered in accordance to pet food legislation (BRASIL, 2003). This study observed that most macronutrient information on the labels were in accordance with the nutritional analysis, but comparison between protein contents analyzed and on label showed a tendency to levels lower than presented on label $(p=0.055)$. Of all the wet diets evaluated for dogs $69.2 \%$ presented fat values and $61.5 \%$ presented protein values higher on the label information than the analyzed levels. For cats, 33.3\% of diets presented fat values and $66.6 \%$ presented protein values higher on the label information than the analyzed levels.

When comparing nutritional analysis and recommended levels of daily nutrient intake, only one diet for dogs did not meet the minimum requirements for protein as suggested by FEDIAF (2016). All other products analyzed supplied at least $100 \%$ of the daily requirement, with mean values of $41.54 \mathrm{~g}$ of CP/100 $\mathrm{g}$ DM and $22.57 \mathrm{~g}$ of $\mathrm{CFa} / 100 \mathrm{~g} \mathrm{DM}$ for dogs and $48.25 \mathrm{~g}$ of CP/100 $\mathrm{g}$ DM and $19.23 \mathrm{~g} \mathrm{CFa} / 100$ g DM for cats (Tables 3 and 4). A positive difference was observed between recommended intake and nutrient provided by the products analyzed. The mean percentage of protein provision from the diets when compared to FEDIAF (2016) was $197.8 \%$ for dogs and $193 \%$ for cats, while mean percentage of fat provision was $410 \%$ for dogs 
and $213.6 \%$ for cats. It is noteworthy that the the nutritional recommendations are made according to the amount of food necessary to meet the energetic needs of each species and each individual based on body weight of the animal, considering for example: $95 \mathrm{kcal} / \mathrm{kg}^{0,75}$ to dogs and 100 $\mathrm{kcal} / \mathrm{kg}^{0.67}$ for cats (FÉDÉRATION EUROPÉENNE DE L'INDUSTRIE DES ALIMENTS POUR ANIMAUX FAMILIERS, 2016).

Table 3 - Protein and fat requirement for adult dogs according to FEDIAF 2016 and supply of these nutrients by each diet - FMVZ/ USP, Pirassununga (SP) - 2017

\begin{tabular}{|c|c|c|c|c|c|c|}
\hline Items & Crude protein (g/100g DM') & Difference $^{2}(\mathrm{CP})(\mathrm{g})$ & Supply (\%) & Crude fat (g/100g DM') & Difference $^{2}(\mathrm{CFa})(\mathrm{g})$ & Supply (\%) \\
\hline \multicolumn{7}{|c|}{ Dogs } \\
\hline FEDIAF dogs ${ }^{3}$ & 21.00 & - & - & 5.50 & - & - \\
\hline Food A & 46.77 & 25.77 & 222.71 & 30.80 & 25.30 & 560,00 \\
\hline Food B & 20.68 & -0.32 & 98.48 & 10.72 & 5.22 & 194.91 \\
\hline Food C & 40.70 & 19.70 & 193.81 & 25.84 & 20.34 & 469.82 \\
\hline Food D & 38.07 & 17.07 & 181.29 & 22.05 & 16.55 & 400.91 \\
\hline Food E & 56.09 & 35.09 & 267.10 & 23.09 & 17.59 & 419.82 \\
\hline Food F & 46.72 & 25.72 & 222.48 & 18.98 & 13.48 & 345.09 \\
\hline Food G & 41.65 & 20.65 & 198.33 & 22.28 & 16.78 & 405.09 \\
\hline Food $\mathrm{H}$ & 44.54 & 23.54 & 212.10 & 24.65 & 19.15 & 448.18 \\
\hline Food I & 36.62 & 15.62 & 174.38 & 12.87 & 7.37 & 234.00 \\
\hline Food J & 39.28 & 18.28 & 187.05 & 36.33 & 30.83 & 660.55 \\
\hline Food K & 38.97 & 17.97 & 185.57 & 30.58 & 25.08 & 556.00 \\
\hline Food L & 42.17 & 21.17 & 200.81 & 19.40 & 13.90 & 352.73 \\
\hline Food M & 47.81 & 26.81 & 227.67 & 15.76 & 10.26 & 286.55 \\
\hline Mean & 41.54 & 20.54 & 197.83 & 22.57 & 17.07 & 410.28 \\
\hline
\end{tabular}

${ }^{1} \mathrm{DM}$, dry matter. ${ }^{2}$ Difference, difference between nutritional composition and FEDIAF (2016) recommendation. ${ }^{3}$ FEDIAF dogs, minimum nutrient requirement for healthy adult dogs based on energy need of $95 \mathrm{kcal} / \mathrm{kg}^{0,75}$ (FÉDÉRATION EUROPÉENNE DE L'INDUSTRIE DES ALIMENTS POUR ANIMAUX FAMILIERS, 2016)

Table 4 - Protein and fat requirement for adult cats according to FEDIAF 2016 and supply of these nutrients by each diet - FMVZ/ USP, Pirassununga (SP) - 2017

\begin{tabular}{|c|c|c|c|c|c|c|}
\hline Items & Crude protein (g/100g DM') & Difference $^{2}(\mathrm{CP})(\mathrm{g})$ & Supply (\%) & Crude fat (g/100g DM') & Difference $^{2}(\mathrm{CFa})(\mathrm{g})$ & Supply (\%) \\
\hline \multicolumn{7}{|c|}{ Cats } \\
\hline FEDIAF cats ${ }^{3}$ & 25.00 & - & - & 9.00 & - & - \\
\hline Food N & 38.11 & 13.11 & 152.44 & 37.50 & 28.50 & 416.67 \\
\hline Food O & 57.67 & 32.67 & 230.68 & 24.00 & 15.00 & 266.67 \\
\hline Food P & 48.52 & 23.52 & 194.08 & 17.50 & 8.50 & 194.44 \\
\hline Food Q & 57.08 & 32.08 & 228.32 & 11.42 & 2.42 & 126.89 \\
\hline Food R & 47.61 & 22.61 & 190.44 & 22.22 & 13.22 & 246.89 \\
\hline Food S & 44.54 & 19.54 & 178.16 & 16.66 & 7.66 & 185.11 \\
\hline Food T & 42.69 & 17.69 & 170.76 & 27.77 & 18.77 & 308.56 \\
\hline Food U & 59.22 & 34.22 & 236.88 & 12.50 & 3.50 & 138.89 \\
\hline Food V & 46.81 & 21.81 & 187.24 & 18.75 & 9.75 & 208.33 \\
\hline Food W & 58.55 & 33.55 & 234.20 & 10.00 & 1.00 & 111.11 \\
\hline Food X & 39.66 & 14.66 & 158.64 & 15.78 & 6.78 & 175.33 \\
\hline Food Y & 38.57 & 13.57 & 154.28 & 16.66 & 7.66 & 185.11 \\
\hline Mean & 48.25 & 23.25 & 193.01 & 19.23 & 10.23 & 213.67 \\
\hline
\end{tabular}

${ }^{1} \mathrm{DM}$, dry matter. ${ }^{2}$ Difference, difference between nutritional composition and FEDIAF (2016) recommendation. ${ }^{3}$ FEDIAF cats, minimum nutrient requirement for healthy adult cats based on energy need of $100 \mathrm{kcal} / \mathrm{kg}^{0,67}$ (FÉDÉRATION EUROPÉENNE DE L'INDUSTRIE DES ALIMENTS POUR ANIMAUX FAMILIERS, 2016) 
The product for dogs that did not meet the daily intake requirements for protein supplied $98.48 \%$ of the recommended levels for this nutrient (FEDIAF, 2016). All commercial pet foods should meet the nutrient requirements (BRASIL, 2003). Levels of protein recommended by FEDIAF (2016) are based on NRC (2006) recommendations and were adjusted to consider protein digestibility of $80 \%$ and lower energy intake due to privately owned animals requiring less energy than laboratory animals (FINCO, 1994; WILLIAMS et al., 2001; THES et al., 2015; THES et al., 2016). If the NRC (2006) crude protein allowance recommended daily be considered for this specific product, it may be observed that this product contains $206.8 \%$ of the crude protein recommended levels. However, NRC (2006) recommended protein requirements are lower than those of FEDIAF (2016) because it considers highly purified protein sources with higher digestibility and animals that have higher energy requirements, which is not the reality of most pets (THES et al., 2015; THES et al., 2016).

Table 5 presents the results of the crude fat content using the three methodologies evaluated in this study. No difference was observed between methods ( $\mathrm{p}=0.68$ ). This may lead to assume that wet foods contain more extractable free lipids, being found in animal tissue and easily extracted with non-polar solvents, than bonded lipids, being found mostly in cereals that require a combination of polar and non-polar solvents or even a previous acid hydrolysis (MCGHEE et al., 1974; LUMLEY; COLWELL, 1991). Another factor that can influence the fat determination method is the formation of nutrient bond complexes. These bonds are mostly formed in the presence of carbohydrates during food processing, especially during extrusion, justifying the recommendation of crude fat acid hydrolysis method of determination for dry foods (MURRAY et al., 2001). As wet foods contain lower amounts of carbohydrates than dry food, there may be less formation of thes bonding complexes, and therefore, there is less influence on the fat determination method choice in wet foods.

Another fact to be considered refers to the differences in the cost of analysis and chemical residue production. Analysis cost varies according to the number of samples and the technology employed. The need to perform previous digestion generates more residues and increases the time to obtain results. Furthermore, the Ankom method allows extraction of 15 samples and recovery of approximately 90\% of solvent used (ANKOM, 2009; LIU, 2011).

Table 5 - Percentages in natural matter of crude fat from wet foods for healthy dogs and cats obtained by three methodologies - FMVZ/USP, Pirassununga (SP) - 2017

\begin{tabular}{|c|c|c|c|}
\hline Items & Crude fat & Crude fat after acid hydrolisis & Ankom XT15 fat analyzer \\
\hline Food A & 5.46 & 4.88 & 5.19 \\
\hline Food B & 5.35 & 4.84 & 5.31 \\
\hline Food C & 2.88 & 2.81 & 3.12 \\
\hline Food D & 7.58 & 8.00 & 8.18 \\
\hline Food E & 9.67 & 9.35 & 9.24 \\
\hline Food F & 3.86 & 3.58 & 4.03 \\
\hline Food G & 4.94 & 4.92 & 3.18 \\
\hline Food H & 5.65 & 5.48 & 7.19 \\
\hline Food I & 5.42 & 5.42 & 5.67 \\
\hline Food J & 3.85 & 3.79 & 3.95 \\
\hline Food K & 5.90 & 5.78 & 6.10 \\
\hline Food L & 3.40 & 3.30 & 3.61 \\
\hline Food M & 4.03 & 3.89 & 5.26 \\
\hline Mean \pm SD $^{1}$ & $5.09 \pm 1.83$ & $4.94 \pm 1.85$ & $5.31 \pm 1.86$ \\
\hline $\mathrm{p}$ & & 0.68 & \\
\hline
\end{tabular}

\footnotetext{
${ }^{1}$ Mean \pm SD, mean values \pm standard deviation from the different methods of fat extraction
} 


\section{Conclusion}

Most wet foods evaluated in this study presented nutritional composition within the Brazilian legal recommendations. Most of the diets analyzed also met the recommendations of the FEDIAF (2016) on the need for fats and proteins of adult dogs and cats, and most exceeded the same recommendations when consumed in quantity to meet the energy needs of each individual. As for the fat content determination methods, the similarity of results

\section{References}

ANKOM. Operator's manual: $\mathrm{ANKOM}^{\mathrm{XT10}}$ extraction system. Macedon, 2009.

ASSOCIATION OF THE OFFICIAL ANALYTICAL CHEMISTS (AOAC). Official Methods of Analysis of AOAC International. Gaithersburg: AOAC International, 2005.

ASSOCIATION OF THE OFFICIAL ANALYTICAL CHEMISTS (AOAC). Official Methods of Analysis of AOAC International. Arlington, VA: AOAC International, 2006.

BARTGES, J. W. Feline calcium oxalate urolithiasis: risk factors and rational treatment approaches. Journal of Feline Medicine and Surgery, v. 18, n. 9, p. 712-722, 2016. doi: $10.1177 / 1098612 X 16660442$.

BRASIL. Ministério da Agricultura, Pecuária e Abastecimento. Instrução normativa n. 9, de 27 de junho de 2003. Diário Oficial da União, Brasília, DF, 30 jun. 2003. Seção 1, p. 4.

BRASIL. Ministério da Agricultura, Pecuária e Abastecimento. Instrução normativa n. 30, de 5 de agosto de 2009. Diário Oficial da União, Brasília, DF, 7 ago. 2009a. Seção 1, p. 13.

CARCIOFI, A. C.; VASCONCELLOS, R. S.; BORGES, N. C.; MORO, J. V.; PRADA, F.; FRAGA, V. O. Nutritional composition and label evaluation of dry food for dogs commercialized in Jaboticabal-SP. Brazilian Archives of Veterinary Medicine and Animal Science, v. 58, n. 3, p. 421-426, 2006. doi: 10.1590/S0102-09352006000300021.

DE-OLIVEIRA, L. D.; TAKAKURA, F. S.; KIENZLE, E.; BRUNETTO, M. A.; TESHIMA, E.; PEREIRA, G. T.; VASCONCELLOS, R. S.; CARCIOFI, A. C. Fibre analysis and indicates that the choice of the method to be used can be made considering the one of easiest applicability for the designed study, residue production, and laboratory chosen to perform the analysis.

\section{Acknowlegements}

We would also like to thank Michael James Stablein of the University of Illinois Urbana-Champaign for the English language review of this work.

fibre digestibility in pet foods: a comparison of total dietary fibre, neutral and acid detergent fibre and crude fibre. Journal of Animal Physiology and Animal Nutrition, v. 96, n. 5, p. 95-906, 2012. doi: 10.1111/j.1439-0396.2011.01203.x.

EARLE, K. E.; KIENZLE, E.; OPITZ, B.; SMITH, P. M.; MASKELL, I. E. Fiber affects digestibility of organic matter and energy in pet foods. Journal of Nutrition, v. 128, n. 12, p. 2798-2800, 1998.

ELIASSON, A. C. Starch in food: structure, function and applications. Abington: Woodhead; Boca Raton: CRC Press, 2004. 624 p.

FARCAS, A. K.; LARSEN, J. A.; FASCETTI, A. J. Evaluation of fiber concentration in dry and canned commercial diets formulated for adult maintenance or all life stages of dogs by use of crude fiber and total dietary fiber methods. Journal of the American Veterinary Medical Association, v. 242, n. 7, p. 936-940, 2013. doi: 10.2460/javma.242.7.936.

FÉDÉRATION EUROPÉENNE DE L'INDUSTRIE DES ALIMENTS POUR ANIMAUX FAMILIERS (FEDIAF). Nutritional guidelines for complete and complementary pet food for cats and dogs. Brussels: FEDIAF, 2016. 100 p.

FINCO, D. R.; BROWN, S. A.; CROWELL, W. A.; BROWN, C. A.; BARSANTI, J. A.; CAREY, D. P.; HIRAKAWA, D. A. Effects of aging and dietary protein intake on uninephrectomized geriatric dogs. American Journal of Veterinary Research, v. 55, n. 9, p. 1282-1290, 1994.

GRIFFIN, R. W. Palatability testing: parameters and analyses that influence test conclusions. In: KVAMME, J. 
L.; PHILLIPS, T. D. Petfood technology. Mt Morris: Watt, 2003, p. 187-193.

HAND, M. S.; THATCHER, C. D.; REMILLARD, R. L.; ROUDEBUSH, P.; NOVOTNY, B. J. Small Animal Clinical Nutrition. 5. ed. Topeka: Mark Morris Institute, 2010. 745 p.

HUBER, T. L.; WILSON, R. C.; MCGARITY, S. A. Variations in digestibility of dry dog foods with identical label guaranteed analysis. Journal of the American Animal Hospital Association, v. 22, n. 5, p. $571-575,1986$.

LANKHORST, C.; TRAN, Q. D.; HAVENAAR, R.; HENDRIKS, W. H.; VAN DER POEL, A. F. B. The effect of extrusion on the nutritional value of canine diets as assessed by in vitro indicators. Animal Feed Science and Technology, v. 138, n. 3-4, p. 285-297, 2007. doi: 10.1016/j.anifeedsci.2006.11.015.

LIU, K. Modification of an AOCS official method for crude oil content in distillers grains and other agricultural materials. Urbana: The AOCS Lipid Library, 2011.

LULICH, J. P.; BERENT, A. C.; ADAMS, L. G.; WESTROPP, J. L.; BARTGES, J. W.; OSBORNE, C. A. ACVIM Small animal consensus recommendations on the treatment and prevention of uroliths in dogs and cats. Journal of Veterinary Internal Medicine, v. 30, n. 5, p. 1564-1574, 2016. doi: 10.1111/jvim.14559.

LUMLEY, I. D.; COLWELL, R. K. Extraction of fats from fatty foods and determination of fat content. In: ROSSEL, J. B.; PRITCHARD, J. L. R. Analysis of oilseeds, fats and fatty foods. New York: Elsevier Applied Science, 1991. p. 238-247.

MCGHEE, J. E.; BLACK, L. T.; BREKKE, O. L. Fat content in corn grits: effects of grinding, extraction solvents, and analytical methods. Cereal Chemistry, v. 51, n. 4, p. $472-477,1974$.

MURRAY, S. M.; FLICKINGER, E. A.; PATIL, A. R.; MERCHEN, N. R.; BRENT JUNIOR, J. L.; FAHEY JUNIOR, G. C. In vitro fermentation characteristics of native and processed cereal grains and potato starch using ileal chyme from dogs. Journal of Animal Science, v. 79, n. 2, p. $435-444,2001$.

NATIONAL RESEARCH COUNCIL (NRC). Nutrient requirements of dogs and cats. Washington, DC: The National Academies Press, 2006. 398 p.

SILVA, D. J.; QUEIROZ, A. C. Food analysis: chemical and biological methods. Viçosa: UFV, 2002.235 p.

TESTER, R. F.; KARKALAS, J.; QI, X. Starch: composition, fine structure and architecture. Journal of Cereal Science, v. 39, n. 2, p. 151-165, 2004. doi: 10.1016/j.jcs.2003.12.001.

THES, M.; KOEBER, N.; FRITZ, J.; WENDEL, F.; DOBENECKER, B.; KIENZLE, E. Metabolizable energy intake of client-owned adult cats. Journal of Animal Physiology and Animal Nutrition, v. 99, n. 6, p. 1025-1030, 2015. doi: 10.1111/jpn12298.

THES, M.; KOEBER, N.; FRITZ, J.; WENDEL, F.; DILLITZER, N.; DOBENECKER, B.; KIENZLE, E. Metabolizable energy intake of client-owned adult dogs. Journal of Animal Physiology and Animal Nutrition, v. 100, n. 5, p. 813-819, 2016. doi: 10.1111/jpn.12541.

TRAN, Q. D.; HENDRIKS, W. H.; VAN DER POEL, A. F. B. Effects of extrusion processing on nutrients in dry pet food. Journal of the Science of Food and Agriculture, v. 88, n. 9, p. 1487-1493, 2008. doi: 10.1002/jsfa.3247.

VANDEPUTTE, G. E.; DELCOUR, J. A. From sucrose to starch granule to starch physical behavior: a focus on rice starch. Carbohydrate Polymers, v. 58, n. 3, p. 245-266, 2004. doi: 10.1016/j.carbpol.2004.06.003.

WEI, A.; FASCETTI, A. J.; VILLAVERDE, C.; WONG, R. K.; RAMSEY, J. J. Effect of water content in a canned food on voluntary food intake and body weight in cats. American Journal of Veterinary Research, v. 72, n. 7, p. 918-923, 2011. doi: 10.2460/ajvr.72.7.918.

WILLIAMS, C. C.; CUMMINS, K. A.; HAYEK, M. G.; DAVENPORT, G. M. Effects of dietary protein on wholebody protein turnover and endocrine function in youngadult and aging dogs. Journal of Animal Science, v. 79, n. 12, p. 3128-3136, 2001. doi:10.2527/2001.79123128x.

Braz. J. Vet. Res. Anim. Sci., São Paulo, v. 54, n. 4, p. 398-406, 2017 